\title{
Study of the social hierarchy and territoriality of Calomys callosus Rengger, 1830 (Rodentia: Cricetidae)
}

\author{
Póvoa, CP. and Brandeburgo, MAM.* \\ Instituto de Genética e Bioquímica, Universidade Federal de Uberlândia - UFU, \\ Av. Eng. Diniz, 1178, CP 593, CEP 38400-902, Uberlândia, MG, Brazil \\ *e-mail: mbrandeburgo@ hotmail.com
}

Received August 1, 2005 - Accepted October 11, Distributed August 31, 2007

(With 4 figures)

\begin{abstract}
The genus Calomys comprises a lot of species distributed throughout South America. The species C. callosus Rengger, 1830 occur in Brazil, been often used in laboratory experiments. This work involved a study of aggressive behavior and dominance, which are aspects related to hierarchy and territoriality, among C. callosus males kept in a laboratory. The establishment of a hierarchy was observed, with the dominant animals controlling the space, food and water, while the remaining animals were confined to a restricted space. The intensity of aggression and variations in the number of attacks declined over time as a result of the formation of the hierarchy. No wounds were observed, probably due to the ritualistic nature of the attacks.
\end{abstract}

Keywords: social hierarchy, territoriality, Calomys callosus.

\section{Estudo da hierarquia social e territorialidade em Calomys callosus}

\begin{abstract}
Resumo
O genêro Calomys inclui várias espécies encontradas na América do Sul. A espécie C. callosus Rengger, 1830 ocorre no Brasil, sendo freqüentemente utilizada em experimentos de laboratório. Neste trabalho foram estudados, em machos mantidos em laboratório, o comportamento agressivo e a dominância, aspectos relacionados à hierarquia e territorialidade. Foi observado o estabelecimento de hierarquia, com os animais dominantes controlando o espaço, o alimento e a água, ficando os demais confinados em um espaço restrito. A intensidade das agressões e as variações no número de ataques diminuiram com o tempo, uma consequiência da formação de hierarquia. Não foram observados ferimentos, devido provavelmente à ritualização dos ataques.
\end{abstract}

Palavras-chave: hierarquia social, territorialidade, Calomys callosus.

\section{Introduction}

The genus Calomys comprises a lot of species distributed throughout South America. The species C. Callosus Rengger, 1830 occur in Brazil, been found in a large, C. expulsus, C. tener, C. tocantinsi, C. laucha and C. callosus and the latter are found in a large variety of habitats, including fields, pasturelands and forest edges. These animals are active principally at night and in the early morning (Nowak, 1991). The species C. callosus, has been used in laboratory experiments (Rodrigues and Ferro, 1998) and the effects of familiarity and privation on its behavior have been analyzed (Ades and Kolde, 1989 and Oliveira and Ades, 1993). In this study, the territorial behavior and the formation of hierarchies among $C$. callosus were observed in a laboratory.

\section{Material and Method}

The animals $C$. callosus of de Canabrava strain came from a resident colony housed at the Institute of Tropical
Medicine in São Paulo. This colony was kindly provided by Judith Kloetzel. The study involved unrelated male animals about 75 days old. In the first experiment, involving 4 animals, the individuals were called Animal 1 (without markings), 2 (marking on the head), 3 (marking in the middle of the body), and 4 (marking close to the tail). The experiment was repeated with another group of animals, marked in the same way and dubbed animals 5, 6, 7 and 8 .

Four individual cages were used $(31 \times 20 \times 12 \mathrm{~cm})$ interconnected by transparent tubes to a larger cage $(41 \times 34 \times 17 \mathrm{~cm})$ called the arena. Each animal was placed in its individual cage, all on the same day and under the same conditions. The animals were kept at room temperature. The food (mice feed) and water were initially available in the individual cages, which were isolated from the arena for the first five days. After that 
period, the animals were allowed free access to the arena, the only place where food and water were now available. The animals were observed nocturnally under red lighting to avoid interferences, and their agonistic interactions recorded. The observations, which began when the animals were allowed access to the arena, lasted for five days. On day 1, the observations began at 7 P.M. and ended at 9 P.M., on day 2 they lasted from 11 P.M. to 1 A.M., on day 3 from 10 P.M. to midnight, on day 4 from 9 P.M. to 11 P.M., and on day 5 from midnight to 2 A.M. After an interval of two days, the observations were repeated for another five days, followed by another 2-day interval and a third 5-day observation period, totaling thirty hours of observation. This procedure was repeated with the second group of four animals.

To quantify the animals' behavior, an analysis was made of the types and frequency of behaviors relating to the conquest and maintenance of hierarchy and territory, taking into account aggressive interactions. Aggressive actions or postures from an attacker towards the attacked were considered attacks. The animals manifested this behavior by standing on their hind legs while attacking with their forelegs and attempting to bite with their teeth.

\section{Results and Discussion}

In the observations conducted during the mornings and afternoons, the individuals were found to be little active. A greater number of attacks occurred in the early hours of nocturnal observation, from 7 to 8 P.M., when the animals began their activities, gradually decreasing thereafter.

Based on the number of attacks each animal made and suffered, a hierarchy or order of dominance was found to have been established. In the first experiment (Table 1), the following order was established, from the most dominant animal (the one that attacked the most or was the least attacked) to the least dominant (the one most attacked and the one attacked the least): Animal 1, Animal 3, Animal 2 and Animal 4. In the second experiment (Table 2), the order of dominance was: Animal 8, Animal 6, Animal 7 and Animal 5.

The dominant animals occupied most of the territory, while the other animals were confined to one of the individual cages. In the first experiment, animals 2 , 3 and 4 were confined to individual cage \# 3 , while in the second experiment, animals 5, 6 and 7 were confined to individual cage \# 2. Whenever they attempted to leave their confinement, these animals were attacked by the dominant individual, which occurred on 22 occasions in the first experiment and on 39 occasions in the second. Whenever the dominant animal was not in the arena, the others made incursions to collect food, carrying it to their area of confinement, where the food was disputed. These observations reveal a relation between aggressiveness, i.e., the number of attacks made and experienced, with the establishment and maintenance of the hierarchy and the conquest of territory by $C$. callosus. This conquest allowed for the dominant animal food and water while the others were obliged to go after these resources only when the dominant individual was absent from the common area.

These findings are evidence of territorial dominance, under the conditions of the experiment. A territory can be defined as the smallest division of a biotope (Hediger, 1964) or any area that is defended (Nice, 1941, apud Nogueira-Neto, 1984). The characteristic common to all territories is that the owner dominates within their limits. The hierarchical organization establishes order in the group of individuals and a high status in the order of dominance provides priority in feeding and reproduction. This experiment revealed three levels of interaction:

Table 1. Number of attacks made and experienced in experiment 1.

\begin{tabular}{cccccc}
\hline \multirow{2}{*}{$\begin{array}{c}\text { Attacked } \\
\text { Animal }\end{array}$} & Animal 1 & Animal 2 & Animal 3 & Animal 4 & $\begin{array}{c}\text { Attacks } \\
\text { experienced }\end{array}$ \\
\cline { 2 - 5 } & - & 92 & 174 & 27 & 293 \\
2 & 194 & - & 120 & 48 & 362 \\
3 & 162 & 118 & - & 44 & 324 \\
4 & 226 & 127 & 122 & - & 475 \\
Total & 582 & 337 & 416 & 119 & - \\
\hline
\end{tabular}

Table 2. Number of attacks made and experienced in experiment 2.

\begin{tabular}{cccccc}
\hline \multirow{2}{*}{$\begin{array}{c}\text { Attacked } \\
\text { Animal }\end{array}$} & Animal 5 & Animal 6 & Animal 7 & Animal 8 & $\begin{array}{c}\text { Attacks } \\
\text { experienced }\end{array}$ \\
\cline { 2 - 5 } & - & 111 & 114 & 208 & 433 \\
6 & 79 & - & 104 & 305 & 488 \\
7 & 57 & 197 & - & 207 & 461 \\
8 & 124 & 204 & 142 & - & 470 \\
Total & 260 & 512 & 360 & 720 & - \\
\hline
\end{tabular}


frankly dominating individuals, intermediary dominance, and frankly dominated individuals.

Vocalizations occurred in all the agonistic encounters. Whenever an attack was successful, the attacked individual fled; if not, the hostile encounter lasted until one of the animals gave up. No wounds were found, which may be evidence that the attacks were ritualized, thus preventing physical harm (Lorenz, 1966).

Figures 1 and 2 indicate that aggressiveness declined as the experiments progressed, as did the variation in responses. Thus, there was a decrease in the average of aggressive responses and in the deviation (Figures 3 and 4). These findings are evidence that, once a hierarchy is established, there is a decline in aggressiveness, while the lower variation may indicate that few interactions are required to maintain a hierarchy that has already been established. According to Tinbergen, 1953 (apud Nogueira-Neto, 1984), the order of dominance has the advantage of reducing disputes and is important from an ecological standpoint, for in times of scarcity, the available food will be reserved preferentially for dominant individuals. One must also consider that a territory favors

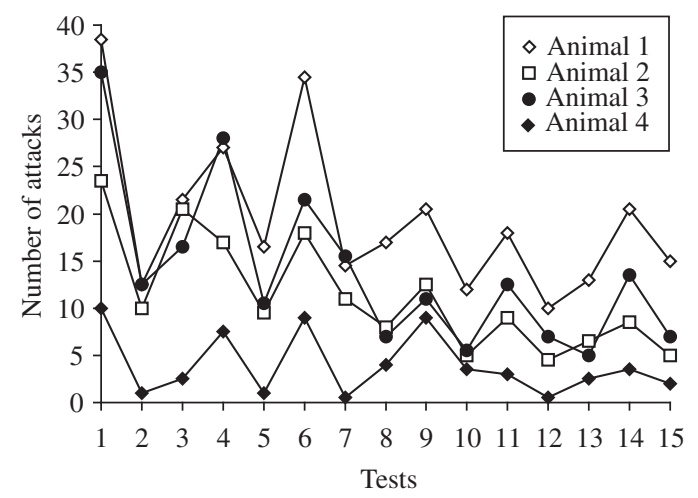

Figure 1. Average number of attacks observed in the first experiment.

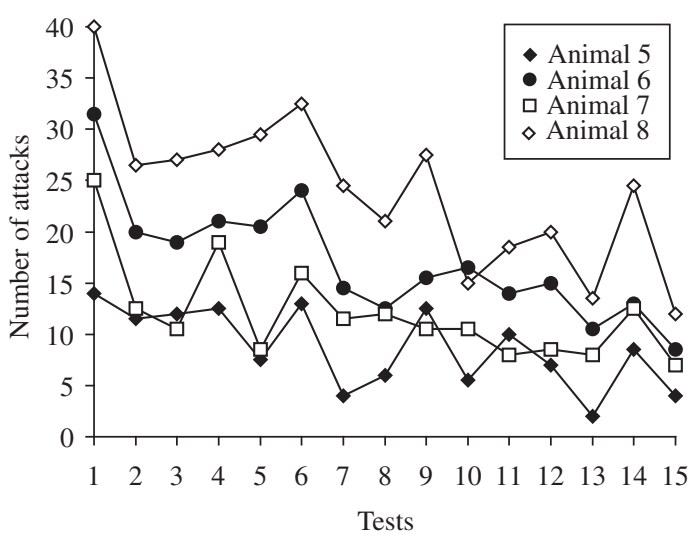

Figure 2. Average number of attacks observed in the second experiment. the formation of pairs and protection against predators (Brandeburgo, 1987). Hence, aggressive behavior connected to hierarchization is an important link to reproduction and territoriality (Lorenz, 1966).

Another finding (Figures 1 and 2) is the similar variation in the animals' responses, with aggressiveness declining or increasing over the same periods, which suggests an environmental influence.

Acknowledgments - We would like to thank Dra. Eloisa A. V. Ferro for the logistic support.

\section{References}

ADES, C. and KOLDE, RE., 1989. The adjustment of Calomys callosus (Rodentia, Cricetidae) to food deprivation. Revista Brasileira de Zoologia, vol. 6, no. 2, p. 219-224.

BRANDEBURGO, MAM., 1987. A importância biológica do comportamento agressivo. Ciência e Cultura, vol. 39, no. 5/6, p. $471-482$

HEDIGER, H., 1964. Wild Animals in Captivity - An outline of the biology of zoological gardens. Dover Publications, Inc. New York.

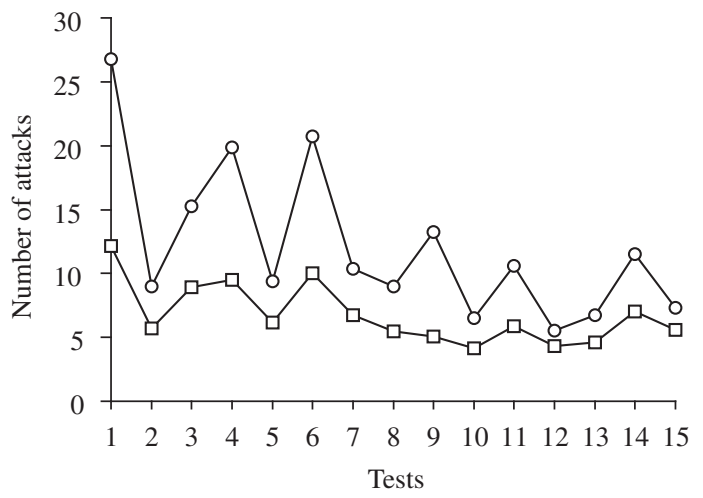

Figure 3. Average $(\bigcirc)$ and standard deviation $(\square)$ of attacks in the first experiment.

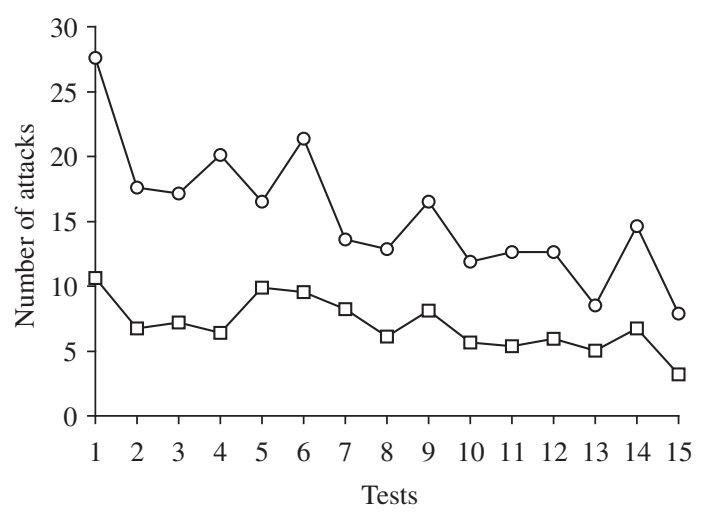

Figure 4. Average $(O)$ and standard deviation $(\square)$ of attacks in the second experiment. 
LORENZ, K., 1966. A agressão. Martins Fontes. São Paulo.

NOGUEIRA-NETO, P., 1984. O comportamento animal e as raízes do comportamento humano. Livraria Nobel S.A. São Paulo.

NOWAK, RM., 1991. Walker's mammals of the world. The Johns Hopkins University Press, Baltimore and London.

OLIVEIRA, DAG and ADES, C., 1993. O Efeito da Familiaridade Sobre o Comportamento de Calomys callosus
(Rodentia: Cricetidae) em ambiente não familiar. $11^{\circ}$ Encontro Anual de Etologia - Anais. Bauru, SP.

RODRIGUES, JFT. and FERRO, EAV., 1998. Morphological changes in the vaginal epithelium during the oestrous cycle of Calomys callosus (Rodentia, Cricetidae). Revista Brasileira de Biologia, vol. 58, no. 3, p. 527-539. 